\title{
PENGGUNAAN APD SAAT PENYEMPROTAN PESTISIDA DAN KADAR KOLINESTERASE DALAM DARAH PETANI DESA PASIRHALANG
}

\author{
Personal Protective Equipment Usage on Pesticide Spraying and Farmer's Blood \\ Cholinesterase Level in Desa Pasirhalang
}

\author{
Gita Nur Fajriani $^{1}$, Suci Rizki Nurul Aeni ${ }^{2}$, Dika Adhi Sriwiguna ${ }^{3}$ \\ ${ }^{1,2,3}$ Sekolah Tinggi Ilmu Kesehatan Rajawali Bandung
}

Korespondensi: gitanurfajriani@gmail.com

\begin{abstract}
Farmers are worker who need personal protective equipment (PPE) in work especially when handling toxic substance like pesticides. Nonetheless formers usually neglect using $P P E$ and thus causing pesticide poisoning. This research aimed to analyze correlation between PPE usage in pesticide spraying and cholinesterase level in Kabupaten Bandung Barat Desa Pasirhalang farmer's blood. Method used in this research is cross sectional analytical survey. They were 43 farmers as sample chosen by non-probability quota sampling method. PPE usage data were collected by semi structured interview and cholinesterase levels by direct examination using Tintometer Kit. Bivariate analysis used chi-square method by computer software. Result showed that $83.7 \%$ farmers didn't used complete PPE and $16.3 \%$ used complete PPE. According to cholinesterase levels examination, $14 \%$ farmers were slight poisoning and $68 \%$ normal. Chi-square analysis value was $0.017(<\alpha=0.05)$. So this research conclude that there is significant correlation between complete PPE usage and cholinesterase level in Kabupaten Bandung Barat Desa Pasirhalang farmer's blood.
\end{abstract}

Keywords : Personal Protective Equipment (PPE), Cholinesterase Level, Pesticide

\begin{abstract}
ABSTRAK
Petani merupakan salah satu pekerja yang membutuhkan alat pelindung diri (APD) dalam bekerja terutama saat menangani pestisida yang sifatnya beracun. Akan tetapi sering kali ditemui petani yang tidak menggunaan APD saat bekerja sehingga berpotensi menyebabkan keracunan pestisida. Tujuan penelitian yaitu untuk mengetahui hubungan antara penggunaan APD pada saat penyemprotan pestisida dengan kadar kolinesterase dalam darah petani di Desa Pasirhalang Kabupaten Bandung Barat. Penelitian menggunakan metode survei analitik dengan pendekatan cross sectional. Sampel terdiri dari 43 petani yang dipilih berdasarkan teknik sampling kuota non-probabilitas. Data penggunaan APD diperoleh dari hasil wawancara semi terstruktur dan data kadar kolinesterasi didapatkan dari pemeriksaan langsung menggunakan alat Tintometer Kit. Analisis chi-square dilakukan dengan bantuan perangkat komputer untuk mengukur hubungan antarvariabel. Hasil penelitian diperoleh 83,7\% petani tidak mengenakan APD lengkap dan 16,3\% mengenakan APD lengkap saat menyemprot pestisida. Berdasarkan pengukuran kadar kolinesterase, $14 \%$ petani mengalami keracunan ringan dan $86 \%$ normal. Hasil analisis chi-square menunjukkan nilai $0,017 \quad(<\alpha=0,05)$. Sehingga disimpulkan terdapat hubungan signifikan antara penggunaan APD lengkap dengan kadar
\end{abstract}

Vol. 10 No. 2, November 2019

DOI: https://doi.org/10.32382/mak.v10i2.1229 
kolinesterasi dalam darah petani.

Kata kunci : Alat Pelindung Diri (APD), Kadar Kolinesterase, Pestisida

\section{PENDAHULUAN}

Petani merupakan kelompok kerja terbesar di Indonesia. Meski terdapat kecenderungan yang semakin menurun, angkatan kerja yang bekerja pada sektor pertanian masih berjumlah sekitar 31,86\% dari jumlah angkatan kerja (Badan Pusat Statistik, 2017). Secara global WHO telah menyurvei bahwa keracunan pestisida pertahunnya dapat mengakibatkan 300.000 kematian dan biasanya terjadi di negara yang berpenghasilan rendah dan menengah. Petani menggunakan berbagai macam pestisida agar tanaman terhindar dari serangan hama yang dapat mengurangi kerugian (Minaka et al., 2016).

Pada manusia paparan pestisida dapat melalui beberapa cara diantaranya melalui minuman, makanan, atau pekerjaan serta melalui rute seperti kulit (dermal), pernapasan (inhalasi), atau mulut (oral) (Alsuhendra, 2013). Masuknya zat beracun pestisida ke dalam tubuh dapat dicegah dengan menggunakan alat pelindung diri (APD). Menurut Permenakertrans RI NO PER.08/MEN/VII/2010 tentang alat pelindung diri (APD) adalah suatu alat yang mempunyai kemampuan untuk melindungi seseorang yang fungsinya mengisolasi sebagian atau seluruh tubuh dari potensi bahaya di tempat kerja. Contoh APD yaitu pelindung kepala (topi), pelindung mata (goggles), pelindung pernapasan (masker) pelindung badan (baju overall/apron), pelindung tangan (glove) dan pelindung kaki (boot) (Djojosumarto, 2008).

Petani yang kurang sadar dalam menggunakan APD pada saat melakukan penyemprotan menjadi faktor risiko terjadinya keracunan pestisida (Ipmawati et al., 2016). Menurut Balai
Penyuluhan Pertanian, Perikanan dan Kehutanan (2016), Desa Pasirhalang adalah salah satu desa yang berada di wilayah Kecamatan Cisarua, Kabupaten Bandung Barat yang berada di kaki Gunung Burangrang yang merupakan daerah perbukitan dan lembah cocok untuk ditanami berbagai sayuran dan penduduknya sebagian besar bertani. Berdasarkan hasil survei awal pada petani di Desa Pasirhalang, petani masih jarang yang memakai APD, karena kurangnya pengetahuan tentang pentingnya menggunakan APD dan tidak ada penyuluhan kepada petani.

Menurut Susilowati, et al (2018), dari 88 petani yang diperiksa didapatkan 12 petani $(13,6 \%)$ dengan kadar kolinerase rendah $(<5,320)$ yang menujukan keracunan pestisida. Faktorfaktor penelitiannya antara lain seperti usia, tingkat pendidikan, waktu terakhir penyemprotan, jenis merk pestisida yang digunakan, pengetahuan tentang pestisida, merokok ketika penyemprotan, dan kelengkapan APD.

Menurut laporan Dinas

Kesehatan Kabupaten Magelang kegiatan pemeriksaan aktivitas kolinesterase darah petani di Kabupaten Magelang Tahun 2010 dari 700 orang yang diperiksa menunjukkan bahwa sebanyak 4 orang mengalami keracunan berat $(0,6 \%)$, keracunan sedang sebanyak 147 orang (21\%), 486 orang $(69,4 \%)$ terindikasi keracunan ringan, dan sebanyak 63 orang normal (9\%). Pada tahun 2012 Dinas Kesehatan melakukan pemeriksaan aktivitas kolinesterase pada 700 sampel darah petani di 7 kecamatan di Kabupaten Magelang dengan hasil sebanyak 5 orang $(0,8 \%)$ keracunan berat, 57 orang $(8,1 \%)$ terindikasi keracunan sedang, 468 orang 
$(66,9 \%)$ terindikasi keracunan ringan, dan sebanyak 170 orang $(24,28 \%)$ dengan hasil normal (Ipmawati, Setiani, Darundiati, 2016).

Berdasarkan latar belakang tersebut dilakukan penelitian untuk menganalisis hubungan antara penggunaan APD lengkap dalam kadar kolinesterase dalam darah petani di Desa Pasirhalang Kabupaten Bandung Barat.

\section{METODE}

Penelitian ini termasuk survei analitik dengan pendekatan cross sectional. Penelitian dilakukan di Desa Pasirhalang Kecamatan Cisarua Kabupaten Bandung Barat pada bulan Juni 2019. Penentuan jumlah sampel berdasarkan rumus prevalensi yaitu 43 petani. Sampel penelitian dipilih menggunakan teknik sampling kuota non-probabilitas dimana Desa Pasirhalang memiliki 11 kelompok tani sehingga dari 10 kelompok tani dipilih masing-masing 4 petani dan dari 1 kelompok tani dipilih 3 petani.

Data yang diperoleh yaitu dari hasil wawancara menggunakan daftar pertanyaan wawancara dan pemeriksaan kolinesterase. Wawancara dilakukan untuk mengetahui kelengkapan APD yang digunakan petani saat menyemprot pestisida.

Data kadar kolinesterasi diperoleh dengan pengukuran langsung menggunakan alat Tintometer Kit. Alat yang digunakan pada penelitian ini yaitu autoklik, blood lancet, cline pipet, kapas alkohol 70\%, Tintometer Kit Lovibond 2000, dan tabung reaksi. Bahan yang digunakan yaitu acetylcholine perchlorat (ACP) 0,25 gr, aquadestilata (bebas CO) $250 \mathrm{~mL}$, dan brom timol blue (BTB) 0,112 gr (sebagai larutan indikator).

Cara kerja dilakukan dalam empat tahap yaitu uji reagen, pengambilan darah, penambahan larutan substratn dan pembacaan hasil. Uji reagen dilakukan dengan menguji indikator dan larutan substrat dengan darah subyek kontrol normal (seorang yang sehat, yang diketahui tidak terpapar dengan pestisida).

Tabung reaksi berisi larutan indikator disiapkan untuk kontrol dan untuk setiap obyek penelitian yang akan diuji. Sampel darah $(0,01 \mathrm{~mL})$ diambil dengan tusukan diujung jari kemudian diambil dengan cline pipet dan dimasukkan dalam tabung reaksi, dicampur hingga homogen.

Setiap tabung ditambahkan larutan substrat $0,5 \mathrm{cc}$ yang dimulai dengan tabung kontrol. Pada saat penambahan substrat ke dalam tabung kontrol waktunya dihitung 0 (nol), kemudian dicatat. Substrat sebanyak 0,5 cc kemudian ditambahkan ke tiap tabung dengan urutan setiap satu menit interval dari set waktu 0 (nol).

Setelah penambahan substrat, larutan dalam tabung kontrol dan sampel akan membentuk warna-warna mulai dari hijau sampai kuning. Warna yang terbentuk dibandingkan dengan satu set kaca berwarna baku standar yang dipasang dalam disk pada alat komparator dalam Tintometer kit. Setiap warna baku menyatakan \% aktivitas enzim kholinesterase. Normal (>75\% $100 \%)$, keracunan ringan pestisida $(>50 \%$ - 75\%), keracunan sedang pestisida $(>25 \%-50 \%)$ dan keracunan berat pestisida (0\% - 25\%). Pengukuran aktivitas enzim kolinesterase dilakukan pada kontrol normal dan sampel darah petani yang telah kontak pestisida.

Data wawancara mengenai penggunaan alat pelindung diri (APD) diubah menjadi data kategorik, dimana bila tidak lengkap dikategorikan 0 , sedangkan lengkap dikategorikan 1 . Data tersebut dan data kadar kolinesterase dalam darah petani kemudian dilakukan uji statistik chisquare untuk mengetahui signifikansi 
korelasi.

\section{HASIL}

Distribusi frekuensi penggunaan APD ditunjukkan pada Tabel 1. APD Tabel 1 menunjukkan bahwa sebagian besar petani tidak menggunakan APD lengkap saat melakukan penyemprotan pestisida.

Distribusi frekuensi kadar kolinesterase dalam darah petani yang kemudian dikategorikan menurut Prijanto (2009) disajikan pada Tabel 2. Tabel 2 menunjukan bahwa sebagai besar petani memiliki kadar kolinesterase berada di kategori normal.

Hasil uji korelasi antara penggunaan APD dengan kadar kolinesterase dalam darah petani disajikan dalam Tabel 3. Tabel 3 hasil uji chi-square menunjukkan nilai $p$-value yaitu 0.017 lebih kecil dari 0.05. Hal tersebut menunjukkan bahwa terdapat hubungan yang signifikan antara penggunaan alat pelindung diri (APD) pada saat penyemprotan pestisida dengan kadar kolinesterase dalam darah petani di Desa Pasirhalang.

\section{PEMBAHASAN}

Alat pelindung diri (APD) yaitu suatu alat yang mempunyai kemampuan untuk melindungi seseorang. Berdasarkan hasil penelitian yang dilakukan $83,7 \%$ petani yang tidak menggunakan alat pelindung diri (APD) lengkap pada saat penyemprotan pestisida.

Menurut Ipmawati et al. (2016), pemakaian masker, topi, sarung tangan, baju lengan panjang dan celana panjang, kaca mata, dan sepatu boot sangat dianjurkan untuk mengurangi risiko masuknya pestisida dalam tubuh yang dapat mempengaruhi kadar kolinesterase.

Berdasarkan hasil wawancara terhadap responden, hampir semua dikategorikan lengkap jika digunakan 6 jenis yaitu topi, masker, baju lengan panjang dan celana panjang, sarung tangan, kaca mata, dan sepatu boot.

responden menyatakan tidak menggunakan alat pelindung diri secara lengkap dikarenakan berbagai alasan seperti tidak nyaman dan tidak terbiasa menggunakan alat pelindung diri. Misalnya kebanyakan petani tidak menggunakan masker dan sarung tangan pada saat penyemprotan pestisida. Sedangkan penggunaan alat pelindung diri yang tidak lengkap akan memudahkan penyerapan pestisida ke dalam tubuh. Hal ini akan diperparah apabila terdapat luka, keringat, serta kondisi kulit tertentu saat melakukan kontak dengan pestisida (Ipmawati et al., 2016). Bahaya keracunan pestisida bisa mengakibatkan keracunan akut contonya (sakit kepala, pusing, mual, sakit dada, sulit bernafas, dll), keracunan subakut, dan keracunan kronis contohnya (gangguan sistem saraf, keseimbangan hormon, hingga terjadinya kanker.

Sejalan dengan penelitian Marisa dan Arrasyid (2017) yang mendapati petani hanya memakai topi dan kaos panjang untuk melindungi diri dari sengatan matahari. Petani beranggapan bahwa keadaan seperti itu sudah biasa. Kondisi ini membuat petani dapat terpapar pestisida lewat jalur pernapasan, inhalasi dan pencernaan.

Kolinesterase adalah suatu enzim yang terdapat pada cairan seluller, yang fungsinya menghentikan aksi asetilkolin dengan jalan terhidrolisis menjadi kolin dan asam asetat. Asetilkolin adalah suatu neuro hormon yang terdapat antara ujung-ujung syaraf dan otot, sebagai media kimia yang fungsinya meneruskan rangsangan syaraf atau impuls ke reseptor sel-sel otot dan kelenjar.

Kadar normal kolinesterase 
dalam darah, laki-laki: $4620 \mathrm{U} / \mathrm{L}-11500$ U/L dan peremuan: $3930 \mathrm{U} / \mathrm{L}-10800 \mathrm{U} / \mathrm{L}$. Akan tetapi dalam penelitian ini dibatasi pengujian dengan menggunakan instrumentasi Tintometer Kit Lovibond 2000 sehingga tidak dilakukan kategorisasi interpretasi menjadi petani laki-laki dan perempuan. Kategorisasi keracunan dalam penelitian ini berdasarkan Prijanto (2009).

Hasil uji kolinesterase yang dilakukan menunjukkan sebagian petani mengalami keracunan ringan dengan kadar enzim kolinesterasi dibawah $75 \%$. Penurunan aktifitas enzim kolinesterase dibawah $75 \%$ merupakan biological marker (biomarker) keracunan senyawa golongan organofosfat. Hasil penelitian diatas dapat dilihat bahwa penurunan kadar enzim kolinesterase disebabkan terpapar pestisida, hal ini berhubungan dengan teori dari Ntow dalam Runia (2008) yang mengatakan bahwa paparan yang disebabkan oleh pestisida bertindak sebagai asetil cholinesterase (AChE) yang akan menurunkan aktivitas kolinesterase dalam darah.

Hasil penelitian juga mendapati bahwa terdapat petani yang tidak memakai APD lengkap tetapi tidak mengalami keracunan. Hal tersebut dapat didukung oleh gaya hidup yang sudah baik seperti pola hidup sehat, makan yang teratur, mengkonsumsi sayur, buah-buahan, dan waktu istrirahat yang cukup. Pada petani yang terpapar organofosfat maka perbaikan baru timbul bila petani diistirahatkan selama beberapa minggu dan selama itu tubuh mensitesis kolinesterase kembali, sehingga kadar kolinesterase akan naik.

Penelitian Raini (2007) pada 80 petani penyemprot pestisida yang keracunan pestisida dengan kolinesterase $\leq 75 \%$, rata-rata subyek memerlukan waktu pemulihan kembali 1 minggu dan untuk kolinesterase $\leq 62.5 \%$ memerlukan waktu 2 minggu.
Berdasarkan hasil wawancara, beberapa petani di Desa Pasirhalang menggunakan pestisida jenis karbamat yang merupakan ester asam Nmetilkarbamat yang bekerja menghambat enzim kolinesterase, tetapi pengaruhnya terhadap enzim tersebut tidak berlangsung lama, karena prosesnya cepat dan reversibel. Bila timbul gejala, gejala itu tidak akan bertahan lama dan cepat kembali normal. Pada umumnya, pestisida jenis ini dapat bertahan dalam tubuh anatara 1 sampai 24 jam sehingga cepat diekskresikan. Kebanyakan petani di Desa Pasirhalang menggunakan pestisida jenis karbamat karena harganya murah dan banyak yang menjualnya di toko-toko pertanian sehingga mudah untuk didapatkan.

Hasil uji stastistik menunjukkan p-value 0,017 lebih kecil dari nilai 0,05 yang berarti terdapat hubungan yang signifikan antara penggunaan alat pelindung diri (APD) dengan kadar kolinesterase dalam darah petani di Desa Pasirhalang.

Pengunaan alat pelindung diri yang tidak lengkap pada saat menyemprot pestisida akan menyebabkan semakin tinggi risiko terpapar pestisida pada responden. Pestisida yang masuk ke tubuh petani dapat menghambat kerja enzim kolinesterasi, sehingga kadar enzim tersebut dapat berkurang.

Penelitian Kurniawan (2009) mengenai hubungan penggunaan APD dengan keracunan pestisida pada petani di Desa Ngrapah Kabupaten Semarang menunjukkan penggunaan masker berhubungan secara signifikan dengan keracunan pestisida ( $p$ value $=0,004)$, tetapi penggunaan sarung tangan tidak berhubungan secara signifikan dengan keracunan pestisida ( $p$ value $=0,170$ ).

Budiono, Jusuf, dan Adriana dalam Kurniawan (2009) berpendapat bahwa APD memang tidak secara 
sempurna dapat melindungi tubuh, tetapi dapat mengurangi tingkat keparahan yang mungkin terjadi. Keracunan pestisida juga dapat diminimalisir dengan menggunakan APD.

\section{KESIMPULAN}

Penelitian menunjukkan penggunaan alat pelindung diri (APD) berhubungan secara signifikan dengan kadar kolinesterase pada petani Desa Pasirhalang Kabupaten Bandung Barat.

\section{SARAN}

Diharapkan petani menggunakan alat pelindung diri (APD) lengkap pada saat kegiatan pertanian. Selain itu perlunya Dinas Kesehatan dan Pertanian, agar dapat melaksanakan penyuluhan rutin tentang pentingnya menggunakan alat pelindung diri (APD) pada saat menyemprot pestisida sesuai aturan.

\section{UCAPAN TERIMA KASIH}

Peneliti mengucapkan terima kasih sebesar-besarnya kepada Kepala Desa Pasir Halang KBB beserta jajarannya dan kepada Balai Penyuluh Pertanian, Perikanan, dan Kehutanan (BP3K) Kecamatan Ngamprah Bandung Barat.

\section{DAFTAR PUSTAKA}

Alsuhendra, R. 2013. Bahan toksik dalam makanan. Latifah $P$, editor. Bandung: PT Remaja Rosdakarya.

Badan Pusat Statistik, Subdirektorat Publikasi dan Kompilasi Statistik, editor. 2017. Statistik Indonesia 2017. Jakarta: Badan pusat statistik.

Dinas Pertanian Perkebunan dan Kehutanan. 2016. Program Penyuluhan Pertanian BP3K Kecamatan Cisarua Tahun 2016. Bandung: Pemerintahan Kabupaten Bandung Barat.

Djojosumarto P. 2008. Pestisida dan
Aplikasinya. Jakarta Selatan: PT Agromedia Pustaka.

Ipnawati PA, Setiani O, Darundiati YH. 2016. Analisis Faktor-faktor Risiko yang Mempengaruhi Tingkat Keracunan Pestisida pada Petani di Desa Jati, Kecamatan Sawangan, Kabupaten Magelang, Jawa Tengah. Jurnal Kesehatan Masyarakat 4(1): 427-435.

Kurniawan, Anggoro. 2009. Hubungan antara Penggunaan Alat Pelindung Diri (APD) dengan Kejadian Keracunan Pestisida pada Petani Penyemprot Hama di Desa Ngrapah Kecamatan Banyubiru Kabupaten Semarang Tahun 2008. Skripsi: Universitas Negeri Semarang.

Marisa, Arrasyid AS. 2017. Pemeriksaan Kadar Pestisida dalam Darah Petani Bawang Merah di Nagari Alahan Panjang. Journal of Sainstek, 9(1): 14-18.

Minaka IADA, Sawitri AAS, Wirawan DN. 2016. Hubungan Penggunaan Pestisida dan Alat Pelindung Diri dengan Keluhan Kesehatan pada Petani Hortikultura di Bulengleng, Bali. Public Health and Preventive Medicine Archive, 4(1): 94-103.

Prijanto TB. 2009. Analisis Faktor Risiko Keracunan Pestisida Organofosfat pada Keluarga Petani Hortikultura di Kecamatan Ngablak Kabupaten Magelang. Semarang: Universitas Diponegoro.

Raini M. 2007. Toksikologi Pestisida dan Penanganan Akibat Keracunan Pestisida. Media Litbang Kesehatan, 17(3): 10-18.

Runia YA. 2008. Faktor-faktor yang Berhubungan dengan Keracunan Pestisida Organofosfat, Karbamat dan Kejadian Anemia 
pada Petani Hortikultura di Desa Tejosari Kecamatan Ngablak Kabupaten Magelang. Tesis: Universitas Diponegoro Semarang.

Susilowati, D. A., Suhartono, S., and Widjanarko, B., 2018. Faktor
Pengetahuan dan Perilaku Petani Penyemprot yang Berhubungan dengan Kadar Serum Cholinesterase di Kabupaten Brebes. Jurnal Epidemiologi Kesehatan Komunitas, 3(2): 6367.

Tabel 1

Distribusi Frekuensi Penggunaan Alat Pelindung Diri (APD)

\begin{tabular}{ccc}
\hline \multirow{2}{*}{$\begin{array}{c}\text { Penggunaan Alat Pelindung Diri } \\
\text { (APD) }\end{array}$} & Jumlah & Distribusi Frekuensi \\
\cline { 2 - 3 } & & 16,3
\end{tabular}




\begin{tabular}{ccc}
$\begin{array}{c}\text { Tidak lengkap bila memakai }<6 \text { jenis } \\
\text { APD }\end{array}$ & 36 & 83,7 \\
\hline Total & 43 & 100 \\
\hline
\end{tabular}

Tabel 2

Distribusi Frekuensi Kadar Kolinesterase dalam Darah Petani di Desa Pasirhalang

\begin{tabular}{|c|c|c|}
\hline \multirow[b]{2}{*}{ Kadar Kolinesterase } & \multicolumn{2}{|c|}{ Distribusi Frekuensi } \\
\hline & Jumlah & $\%$ \\
\hline Keracunan berat $(0 \%-<25 \%)$ & 0 & 0 \\
\hline Keracunan sedang $(25 \%-<50 \%)$ & 0 & 0 \\
\hline Keracunan ringan $(50 \%-<75 \%)$ & 6 & 14 \\
\hline$(75 \%-100 \%)$ & 37 & 86 \\
\hline Total & 43 & 100 \\
\hline
\end{tabular}

Tabel 3

Hasil Uji Korelasi Penggunaan Alat Pelindung Diri dengan Kadar Kolinesterase dalam Darah Petani

\begin{tabular}{ccc}
\hline & Df & p-value \\
\hline Pearson Chi-Square & 4 & .017 \\
\hline
\end{tabular}

